\title{
Teachers, Teaching and Student Achievement
}

\author{
Ivana Đerić, Ines Elezović, and Falk Brese
}

\begin{abstract}
Education policymakers, researchers, and practitioners around the world have dedicated considerable attention to teachers and their instructional practice in their efforts to improve student outcomes. The professional characteristics of teachers and their classroom behaviors may be important in determining how students acquire knowledge and develop skills in mathematics and science, and the relationships between teacher quality, instructional practice, and grade four student outcomes are consequently of great interest to researchers and policymakers. Analysis of IEA's Trends in International Mathematics and Science Study (TIMSS) data indicates that grade four students are taught by teachers with similar educational backgrounds across the Dinaric region. Teacher quality (as measured by experience, level of education, and professional development) was related only to some aspects of instructional practice in the Dinaric region. Teacher quality was not a statistically significant predictor for student achievement in mathematics and science, although teachers' formal education and years of experience were related to some aspects of student achievement.
\end{abstract}

Keywords Instructional practice $\cdot$ Student achievement $\cdot$ Teacher quality $\cdot$ Trends in International Mathematics and Science Study (TIMSS)

\footnotetext{
I. Đerić $(\bowtie)$

Institute for Educational Research, Belgrade, Serbia

I. Elezović

National Centre for External Evaluation of Education, Zagreb, Croatia

e-mail: ines.elezovic@ncvvo.hr

F. Brese

International Association for the Evaluation of Educational Achievement (IEA), Hamburg, Germany

e-mail: falk.brese@ iea-hamburg.de
} 


\section{Introduction}

Educators and researchers have consistently recognized and empirically shown that teachers and their classroom behaviors contribute more to student achievement than other systemic factors in education (Creemers \& Kyriakides, 2008). Many countries have increased the educational requirements for class teachers in primary education to improve the quality of teaching and thereby student achievement in mathematics and science. Traditionally, formal education and experience are used as the principal measures of teacher quality (Burroughs \& Chudgar, 2017). Formal teaching qualifications may also include participation in continuous professional development (PD) (Nilsen et al., 2018). Goe (2007) defined teacher quality as a combination of teachers' backgrounds (teacher qualifications and teacher characteristics), a process measure (teacher practices), and an outcome measure (teacher effectiveness). Some characteristics of teachers' classroom behavior were ambiguous in terms of their relevance for student achievement in mathematics and science across education systems (Blömeke et al., 2016; Nilsen et al., 2018; OECD [Organisation for Economic Cooperation and Development], 2020); however, these studies also claimed that the professional knowledge and skills of teachers had equally important effects on student achievement, regardless of the specific characteristics of education systems, teaching practices, and student behavior in different settings. For example, cognitive activation, supportive classroom interactions, and classroom management have a positive effect on students' achievement in mathematics and science (Decristan et al., 2016).

In short, the importance of teacher characteristics, instructional practice, and their relation to student achievement is evident from the literature. In this chapter, we examine the status of the teaching profession, initial education, and professional development, describing the similarities and differences across the education systems in the Dinaric region. Our regional analyses of IEA's Trends in International Mathematics and Science Study (TIMSS) 2019 provide in depth information about the relationships between the quality of teachers, instructional practice in participating classes, and grade four student outcomes on the TIMSS test. This supplies an evidence base for future investigation into the effectiveness of the strategies for improvement suggested by this research. Seven participants from the Dinaric region took part in TIMSS 2019, namely Albania, Bosnia and Herzegovina, Croatia, Kosovo, ${ }^{1}$ Montenegro, North Macedonia, and Serbia.

\section{Teachers and the Teaching Profession in the Dinaric Region}

Teachers who work in primary schools (e.g., at grades one to four) are called class teachers in all education systems in the Dinaric region. The classes are taught by

\footnotetext{
${ }^{1}$ All references to Kosovo in this document should be understood to be in the context of United Security Council resolution 1244 (1999).
} 
one teacher, except in specific cases, when some subjects may be taught by specialized subject teacher (e.g., English language). In the majority of TIMSS classes in the Dinaric region, class instruction is delivered in official languages and/or the languages of national minorities; the region is ethnically and culturally diverse. Most teachers of lower grades in primary school acquire their degree from teacher training faculties (state and/or private) across the Dinaric region. These faculties are oriented towards pedagogical, methodical, and didactical studies into subjects taught in primary education. In Albania, Croatia, Kosovo, and Serbia, a master's level qualification (ISCED [International Standard Classification of Education] 7; see UNESCO [United Nations Educational, Scientific and Cultural Organization] Institute of Statistics, 2012 for an explanation of the ISCED classifications) is the minimum level of initial teacher education required for employment in primary schools. In Bosnia and Herzegovina, Montenegro, and North Macedonia, a bachelor level qualification (ISCED 6) is required for teachers of grade four students. After completing their academic studies, to gain employment as a teacher, candidate teachers must also pass a state examination for teacher certification (except in Bosnia and Herzegovina). In most education systems in the Dinaric region, young teachers enter an initiation program at the beginning of their careers to introduce them to the teaching profession. Professional orientation is provided through different types of mentoring by more experienced teachers. All education systems in the region have an induction period, which varies slightly in duration and ranges from a minimum of six months to, more commonly, a full year of probation before a teacher can be fully registered as a professional (Pantić et al., 2011).

Teachers from the Dinaric region have an obligation to develop professionally during their careers by attending state-organized training courses. The state agencies and institutes have the leading role in creating professional development policies and in their implementation. While some education systems in the Dinaric region have mechanisms in place to accredit providers and programs, others are struggling to implement a coherent system (e.g., Bosnia and Herzegovina). Across the region, training programs are provided by public, scientific, and professional associations and/or private institutions. Most teachers from the region choose the programs they wish to attend from a list of accredited training programs approved by the state agencies.

There are between-systems differences in the amount of time teachers need to dedicate to PD across the Dinaric region. Croatian teachers are obliged to participate in PD programs in accordance with a proscribed number of hours at the state, county, and school level (Elezović \& Muraja, 2020; Viorel, 2017). Teachers from Kosovo, depending on career development paths, and on the criteria and conditions for licensing by the type of license, must ensure that they have the number of required hours of PD (Mehmeti et al., 2019). Teachers in North Macedonia are expected to $\log$ at least $60 \mathrm{~h}$ of PD over three years (OECD, 2019a), while teachers from Albania must undertake at least three days training per year (Vrapi \& Alia, 2020). Serbian teachers are required to undertake $64 \mathrm{~h}$ of various PD activities annually. A required number of teacher PD training hours is not stipulated at the state level in Bosnia and 
Herzegovina or Montenegro (Duda et al., 2013; Popić \& Džumhur, 2020). Nevertheless, policymakers and school leaders need to ensure that PD opportunities are available for all teachers across the region.

High-quality PD activities are recognized as crucial if education systems are to ensure that all teachers possess and maintain the relevant competencies to be effective in modern classrooms (Viorel, 2017). Several studies have shown that teachers in the Dinaric region face very similar challenges concerning PD. Firstly, PD programs in the Dinaric area are usually designed as one-off seminars and courses (Pantic et al., 2011). In Bosna and Herzegovina, Kosovo, Montenegro, and North Macedonia, teachers and researchers have expressed concern both about the quality and the availability of training courses (Mehmeti et al., 2019; Mićanović \& Vučković, 2014; OECD, 2019a). In Serbia, seminars are still often fragmentary, unrelated to teaching practice, insufficiently intensive, and lack the necessary follow-up and support, according to educational experts, school principals, school counselors, and experts in pedagogy and psychology (Đerić et al., 2014). Likewise, educational authorities have observed that teacher training in Bosnia and Herzegovina is outdated, does not follow current education trends, and does not support the progress of teachers (Popić \& Džumhur, 2020). By contrast, the OECD's Teaching and Learning International Survey (TALIS) 2018 found that a very high percentage of Croatian teachers $(86 \%)$ reported that the PD activities that they attended had a positive impact on their teaching practice (OECD, 2019b). However, for most teachers across the Dinaric region, the budget devoted to $\mathrm{PD}$ is insufficient to access opportunities to become involved in PD activities (OECD, 2009; Viorel, 2017). For teachers across the region, which teacher competencies should be developed, which professional knowledge should be offered to teachers within PD training, how much time needs to be dedicated to PD, and how PD activities can be organized efficiently remain open questions.

Teachers who participated in OECD's Programme for International Student Assessment (PISA) 2018 from the Dinaric region education systems "rely heavily on traditional pedagogy, such as lecturing to students and encouraging them to memorize information set out in the curriculum" (OECD, 2020, p. 65). This last report showed that pedagogical methods in the region (as perceived by students) were still largely traditional and associated with lower student performance. Prior to TIMSS 2019, little data had been gathered on the quality of instructional practice in the primary grades of elementary school across the Dinaric region. In addition, there was a lack of comprehensive and joint research on the quality of instructional practices in the Dinaric region, especially for mathematics and science in lower grades. Our analyses of the TIMSS 2019 data examines the relationship between quality of teachers, instructional practice in classrooms, and grade four students' achievement.

\section{Methods and Research Questions}

Over time, an extensive literature has been developed on teacher quality, instructional quality, and students' outcomes based on international data (e.g., Đerić et al., 2017; 
Nilsen \& Gustafsson, 2016). Several education systems from the Dinaric region did not participate in previous TIMSS assessments of students in mathematics and science at grade four (e.g., Bosnia and Herzegovina, Kosovo, Montenegro, and North Macedonia). Added to this, there are not many regional or national studies examining the relations between teacher quality, instructional practice, and outcomes for representative samples of grade four students in the Dinaric region. Our interest is in describing the "teachers' profile" for the sampled TIMSS 2019 grade four classrooms in the Dinaric region and examining whether, and to what extent, teacher quality and instructional practice contribute to grade four student achievement in mathematics and science. We look in depth at: (1) teacher quality; (2) instructional practice; (3) the relationship between teacher quality and instructional practice; and (4) instructional practice as a factor related to student achievement in mathematics and science.

For our analyses, we focused on three research questions:

(1) What are the similarities and differences, in terms of teacher quality and instructional practices, across the different education systems of the Dinaric region?

(2) Is teacher quality related to aspects of instructional practice across the Dinaric region?

(3) Does the instructional practice of teachers contribute to student achievement when controlling for teacher quality? If so, does student achievement in mathematics and science depend on the relationship between teacher quality and instructional practice?

\subsection{Sample and Data Sources}

Teachers who complete TIMSS questionnaires represent the teachers of a national sample of students (Martin et al., 2020). We used the data obtained from teacher questionnaires in conjunction with achievement test data measuring students' mathematics and science outcomes. Instruments were administered in both the official language and minority languages of the respective education systems in the Dinaric region (except in Serbia, where materials were administrated only in the official language). Teachers' data are interpreted by the percentage of students who are taught by teachers with a specific characteristic. More general information about the analysis methods, sample characteristics, and data sources that we used are available in Sects. 5 and 5.1.

\subsection{Variables and Measures}

We identified several variables and scales in the TIMSS 2019 international reports as being of potential interest for our research (Table 1, see also Table S.11 in the supplementary materials at www.iea.nl/publications/RfEVol13). 
Table 1 List of the variables and scales used in analyses

\begin{tabular}{|c|c|c|c|}
\hline Variables & Description & Values/Response options & References \\
\hline $\begin{array}{l}\text { Teacher's years of } \\
\text { experience }\end{array}$ & $\begin{array}{l}\text { Years of experience as a } \\
\text { teacher altogether }\end{array}$ & Number (years) & $\begin{array}{l}\text { Fishbein et al. (2021, } \\
\text { Supplement 3, p. 71) }\end{array}$ \\
\hline Teacher education & $\begin{array}{l}\text { Teacher's highest level of } \\
\text { formal education completed }\end{array}$ & $\begin{array}{l}\text { Recoded from seven to three } \\
\text { categories } \\
\text { (1) Did not complete } \\
\text { Bachelor's or equivalent } \\
\text { level } \\
\text { (2) Bachelor's or equivalent } \\
\text { level } \\
\text { (3) Completed postgraduate } \\
\text { degree }\end{array}$ & $\begin{array}{l}\text { Fishbein et al. (2021, } \\
\text { Supplement 3, p. 71) }\end{array}$ \\
\hline $\begin{array}{l}\text { Mathematics/science } \\
\text { teachers' major subject of } \\
\text { study }\end{array}$ & $\begin{array}{l}\text { Combination of teachers' } \\
\text { reports on major area of } \\
\text { study and specialization }\end{array}$ & $\begin{array}{l}\text { There were three categories: } \\
\text { (1) Major in primary } \\
\text { education and } \\
\text { mathematics } \\
\text { (2) Major in primary } \\
\text { education but not in } \\
\text { mathematics } \\
\text { (3) Others }\end{array}$ & $\begin{array}{l}\text { Fishbein et al. (2021, } \\
\text { Supplement 3, p. 71) }\end{array}$ \\
\hline $\begin{array}{l}\text { Professional development } \\
\text { teaching } \\
\text { mathematics/science }\end{array}$ & $\begin{array}{l}\text { Numbers of hours teachers } \\
\text { devoted to professional } \\
\text { development in teaching } \\
\text { mathematics/science in the } \\
\text { past two years (recoded } \\
\text { from five to three } \\
\text { categories) }\end{array}$ & $\begin{array}{l}\text { (1) } 16 \mathrm{~h} \text { and more } \\
\text { (2) } 6-15 \mathrm{~h} \\
\text { (3) Less than } 6 \mathrm{~h}\end{array}$ & $\begin{array}{l}\text { Fishbein et al. (2021, } \\
\text { Supplement 3, pp. } 80 \text { and } \\
86)\end{array}$ \\
\hline $\begin{array}{l}\text { Professional development } \\
\text { needs in teaching } \\
\text { mathematics/science }\end{array}$ & $\begin{array}{l}\text { Teachers indication of } \\
\text { needs for professional } \\
\text { development in teaching } \\
\text { mathematics (seven areas) } \\
\text { or teaching science (eight } \\
\text { areas) }\end{array}$ & $\begin{array}{l}\text { There were two response } \\
\text { options per item: } \\
\text { (1) Yes } \\
\text { (2) No }\end{array}$ & $\begin{array}{l}\text { Fishbein et al. (2021, } \\
\text { Supplement 3, pp. } 80 \text { and } \\
86)\end{array}$ \\
\hline $\begin{array}{l}\text { Instructional time for } \\
\text { teaching } \\
\text { mathematics/science }\end{array}$ & $\begin{array}{l}\text { Teacher reports on the time } \\
\text { spent on teaching } \\
\text { mathematics/science to the } \\
\text { TIMSS class in a typical } \\
\text { week }\end{array}$ & Number (minutes) & $\begin{array}{l}\text { Fishbein et al. (2021, } \\
\text { Supplement 3, pp. } 76 \text { and } \\
81)\end{array}$ \\
\hline $\begin{array}{l}\text { Instructional practice in } \\
\text { mathematics }\end{array}$ & $\begin{array}{l}\text { Teachers reports on } \\
\text { frequency of asking } \\
\text { students to apply what they } \\
\text { have learned to new } \\
\text { problem situations on their } \\
\text { own every or almost every } \\
\text { lesson }\end{array}$ & $\begin{array}{l}\text { Index with four categories: } \\
\text { (1) Every or almost every } \\
\text { lesson } \\
\text { (2) About half of the } \\
\text { lessons } \\
\text { (3) Some lessons } \\
\text { (4) Never }\end{array}$ & $\begin{array}{l}\text { Fishbein et al. (2021, } \\
\text { Supplement 3, p. 76) }\end{array}$ \\
\hline
\end{tabular}

\section{Teacher Quality}

A set of questions in the TIMSS grade four teacher questionnaire (TIMSS \& PIRLS International Study Center, 2018) asked teachers about their educational background: namely, their formal education, specialization, experience, the number of hours they 
Table 1 (continued)

\begin{tabular}{l|l|l|l}
\hline Variables & Description & Values/Response options & References \\
\hline $\begin{array}{l}\text { Instructional practice in } \\
\text { science }\end{array}$ & $\begin{array}{l}\text { Teachers reports on } \\
\text { frequency of asking } \\
\text { students to use evidence } \\
\text { from experiments or }\end{array}$ & $\begin{array}{l}\text { Index with four categories: } \\
\text { (1) Every or almost every }\end{array}$ & $\begin{array}{l}\text { Fishbein et al. (2021, } \\
\text { lesson }\end{array}$ \\
& $\begin{array}{l}\text { (2) About half of the } \\
\text { investigations to support } \\
\text { conclusions }\end{array}$ & $\begin{array}{l}\text { (3) Some lessons } \\
\text { (4) Never }\end{array}$ & \\
& & (4) Nens & \\
\hline
\end{tabular}

had devoted to PD in teaching mathematics and science, and whether they had participated in PD during the last two years.

\section{Instructional Practice}

Teachers were asked to report how often they performed various activities in the TIMSS sampled mathematics and science classes they were teaching to ("In teaching mathematics/science to this class, how often do you ask students to do the following?"). Our measure of instructional practice is based on their responses to two of the items: namely, how often they asked students in their teaching to "apply what they have learned to new problem situations on their own" during mathematics lessons, and "use evidence from experiments or investigations to support conclusions" during science lessons.

\section{Student Outcomes}

Student outcomes include both mathematical achievement and science achievement in the TIMSS 2019 test. Mathematical and science achievement are represented by five plausible values representing student achievement and all five plausible values were used in our analyses.

\section{Results and Discussion}

\subsection{Teacher Quality in the Dinaric Region}

The educational background of mathematics and science teachers was similar across the Dinaric region. Most grade four students had teachers that possessed a bachelor's degree or an equivalent qualification (ISCED level 6), but not a postgraduate degree. Teachers from Albania and Croatia had the highest levels of education; more than half of them had some kind of postgraduate university degree (M.A., Ph.D., or other postgraduate qualification). For most teachers from the Dinaric region, this level of formal education is in line with the policy recommendations and requirements of the European Union (EU) (Table 2). Several large-scale studies suggest that, while teachers in many education systems are well educated (Mullis et al., 2020; Schleicher, 


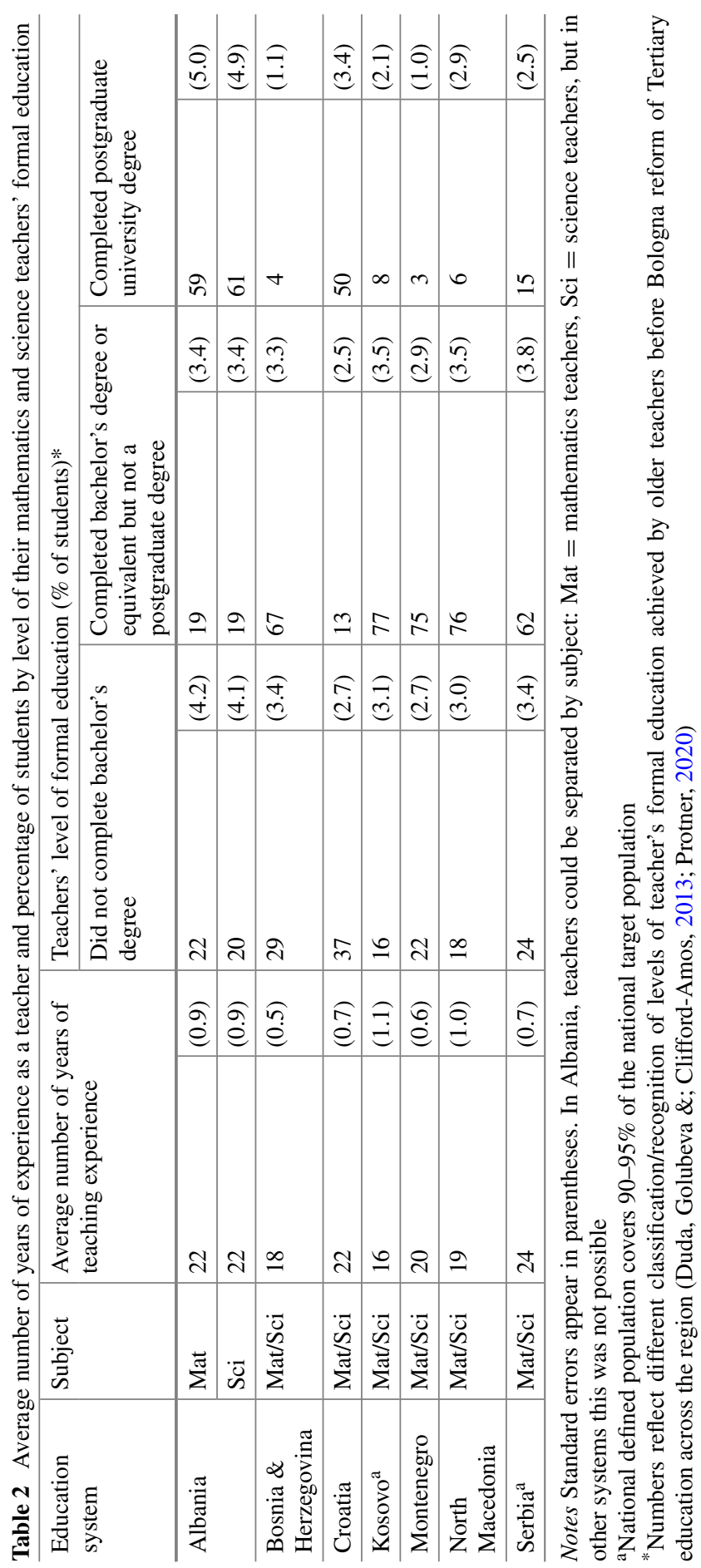




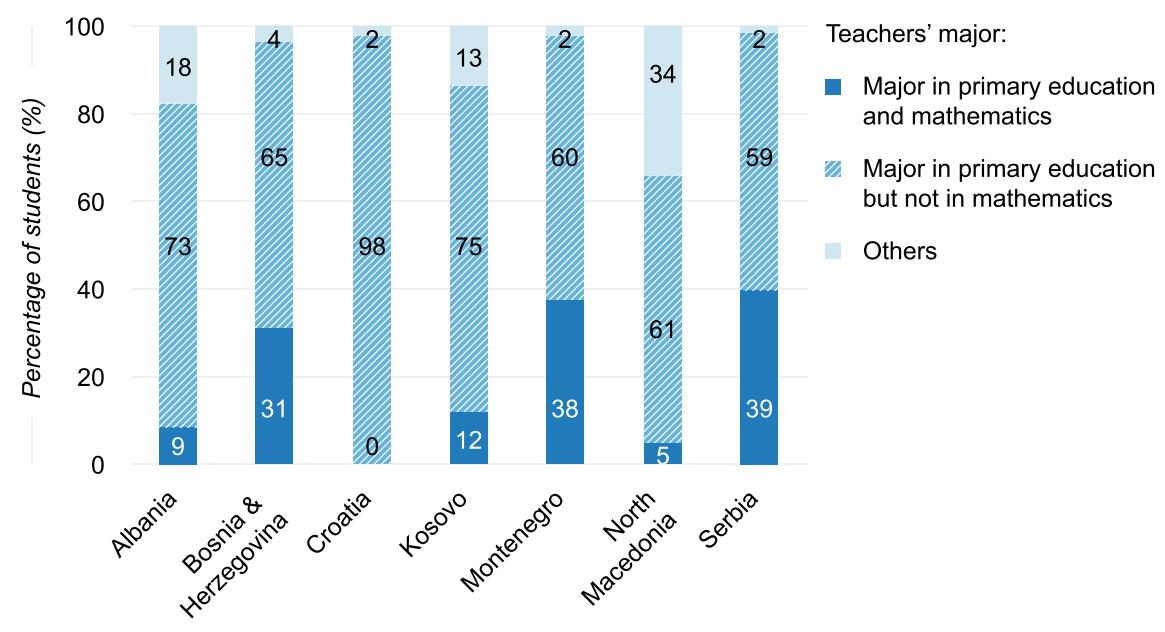

Fig. 1 Percentage of students taught by teachers whose major subject of study was mathematics. Note In Kosovo and Serbia, the national defined population covers $90-95 \%$ of the national target population

2020), there is still a notable percentage of teachers around the world that possess low levels of formal education.

Most students in the Dinaric region had teachers who, on average, were slightly more experienced (Table 2) than their colleagues in the other education systems that participated in TIMSS 2019. Teachers from Bosnia and Herzegovina, Kosovo, and North Macedonia, on average, had less than 20 year of teaching experience, which was closer to the international average (mean $=17$ years; Mullis et al., 2020). Serbian grade four students had most experienced teachers in the region.

Teachers were also asked what their major or main area(s) of study were during their academic education. For most teachers, the focus of their academic education was teaching primary education, without any specialization in mathematics and science (Figs. 1 and 2); this finding is consistent with the pedagogical orientation of teacher training faculties across the Dinaric region. Most students had teachers whose major subject of study was teaching in elementary schools/primary education. Only very few students $(<10 \%)$ were taught by teachers who studied for a degree in mathematics or science or another academic subject. The PISA 2018 report found no relationship between teacher qualifications and student outcomes in the Western Balkans (OECD, 2020). While a recent study showed that teacher specialization could be linked to effective teaching practices and student achievement of grade four students in Sweden (Johansson \& Myberg, 2019), initial teacher education is often insufficient to prepare primary and secondary teachers for their challenging jobs. Highly qualified teachers must possess full state certification, a master's degree, and demonstrate subject matter competency in each of the academic subjects they teach. Teachers also need high quality PD activities to develop relevant competencies to be effective in modern classroom conditions (OECD, 2020; Viorel, 2017). 


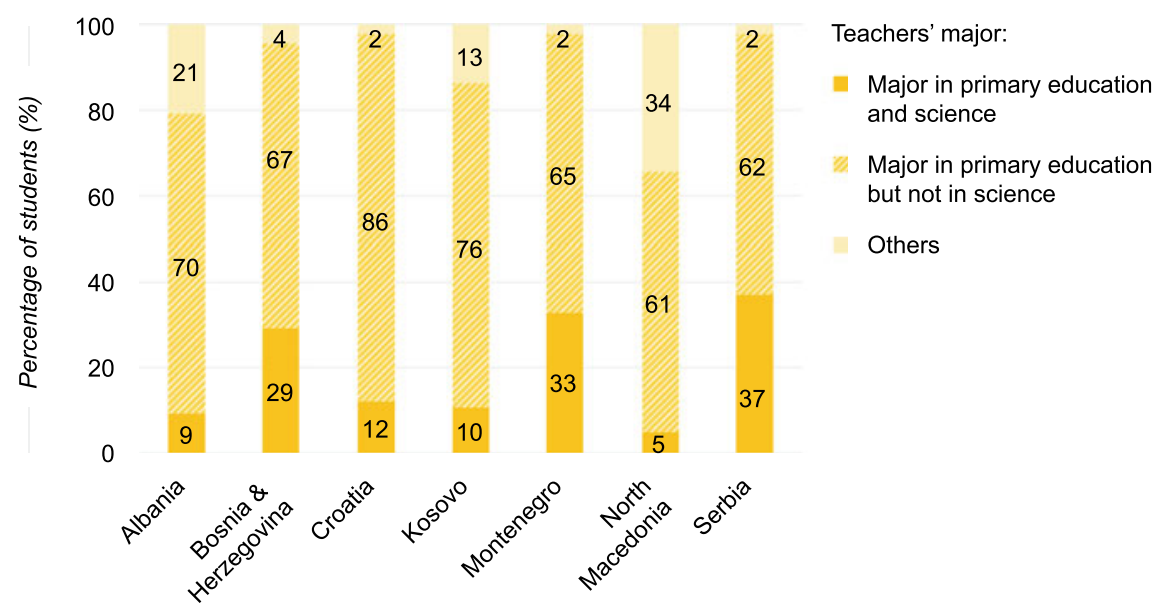

Fig. 2 Percentage of students taught by teachers whose major subject of study was a science. Note In Kosovo and Serbia, the national defined population covers $90-95 \%$ of the national target population

As part of the TIMSS 2019 teacher questionnaire, teachers in the Dinaric region reported how many hours they had spent undertaking formal PD activities (such as workshops and seminars) related to teaching mathematics and science over the last two years. We divided the data collected into the following three categories: (1) $16 \mathrm{~h}$ and more; (2) 6-15 h; and (3) less than six hours. In general, the level of PD across the region was low (Figs. 3 and 4).

Overall, Dinaric grade four students were taught by class teachers that spent more time on PD activities that were related to teaching mathematics than teaching science, although the difference was not prominent (except for Albania and Montenegro). Almost $40 \%$ of the students from Kosovo had teachers who devoted $16 \mathrm{~h}$ or more PD to teaching mathematics, which is significantly higher level than was reported by teachers from other education systems in the Dinaric region. Alarmingly, more than half the students from Bosnia and Herzegovina (85\%), Croatia (65\%), North Macedonia (61\%), and Albania (54\%) were taught by teachers who reported dedicating less than six hours to PD in mathematics over the previous two years. The figures reported for teacher PD related to teaching science were even lower than those for mathematics. A large percentage of grade four students from Bosnia and Herzegovina ( $81 \%$ ) and North Macedonia $(76 \%)$ have teachers who dedicated less than six hours to PD in science. The largest percentage of grade four students $(23 \%)$ whose teachers reported spending $16 \mathrm{~h}$ or more on PD in science was in Kosovo.

Teachers of the grade four students in the Dinaric region spent more time on PD for mathematics than for science teaching, but there was also wide variation among teachers across the region in terms of overall time invested in PD. Teachers from Kosovo reported investing the greatest amount of time on PD in mathematics and science, while teachers from Bosnia and Herzegovina, Croatia, and North Macedonia 


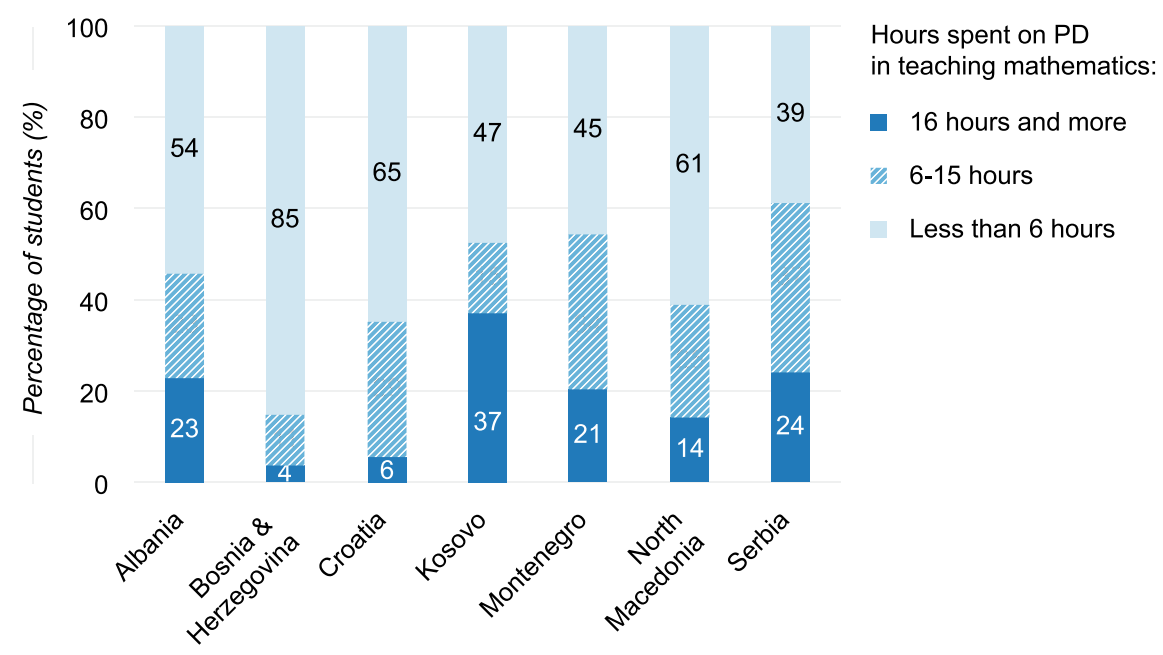

Fig. 3 Percentage of students taught versus number of hours their teachers devoted to professional development in teaching mathematics over the previous two years. Note In Kosovo and Serbia, the national defined population covers $90-95 \%$ of the national target population

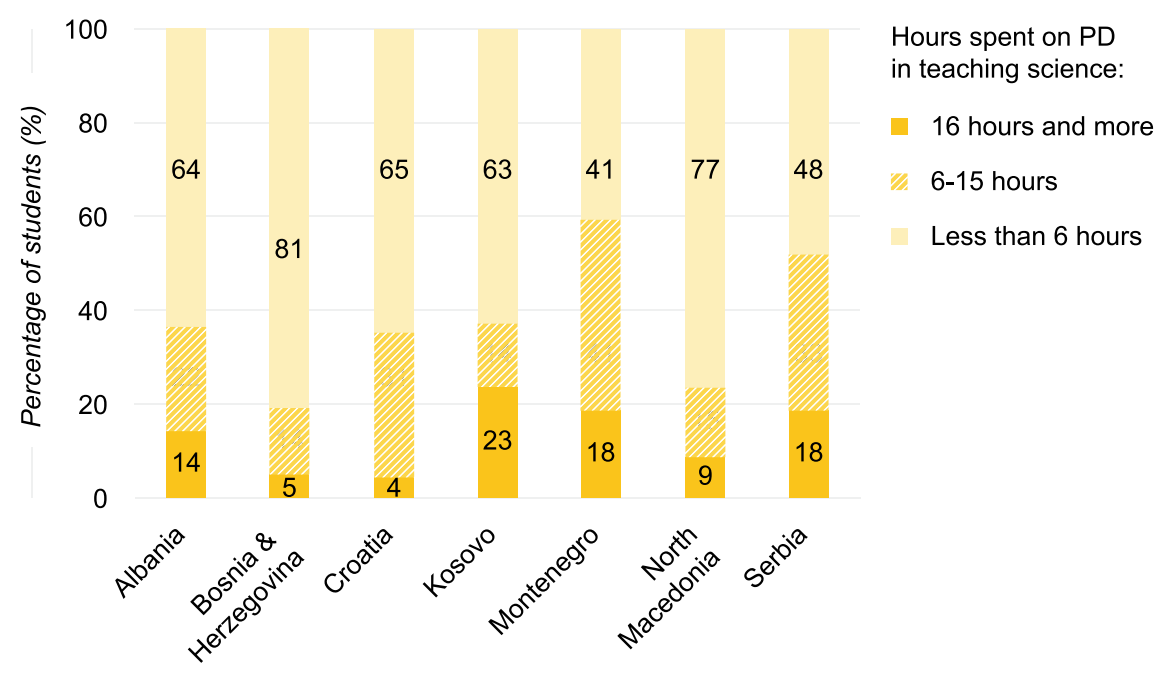

Fig. 4 Percentage of students taught versus number of hours their teachers devoted to professional development in teaching science over the previous two years. Note In Kosovo and Serbia, the national defined population covers $90-95 \%$ of the national target population 
reported little time was invested on PD. Recent study shows that long-term PD programs are more effective, both in terms of the overall amount of time that the activity takes, and the total amount of hours spent (Barrera-Pedemonte, 2016).

Teachers were further asked if they had participated in content-specific (but not necessarily formal) PD activities over the previous two years. The question included the following categories of answers for both subject areas: (1) content; (2) pedagogy/instruction; (3) curriculum; (4) integrating technology into instructions: (5) improving students' critical thinking or problem-solving skills; (6) assessments; (7) addressing individual students' needs; and (8) addressing students' language needs in learning mathematics or science. However, grade four teachers across the whole region stated that the most pressing future need in the field of mathematics and science PD was integrating technology into instruction (Tables 3 and 4). This is in line with the development and application of technologies to other areas of society, and growing interest in teaching children and youth how to use ICT at school and in everyday life (IEA, 2021).

Many teachers across the region noted a need for PD in addressing individual student needs and improving students' critical thinking and problem-solving skills (Tables 3 and 4). Their interest in these themes indicates that teachers of grade four students are aware of the generic competencies they should focus on developing in their students. We can postulate that a desire for support to help them develop skills in innovative teaching methods is seen as a way to improve teaching efficiency and enhance students' results. Analysis of the TIMSS data across many education systems supports the conclusion that students of teachers at grade four who improved their professional knowledge of mathematics content through undertaking PD activities tend to have higher achievement scores than other students (Liang et al., 2015).

\subsection{Instructional Practice in the Dinaric Region}

There was large reported variation in the time devoted to mathematics and science instruction among the education systems in the Dinaric region (see also chapter "Opportunity to Learn Mathematics and Science"). On average, grade four students from Kosovo and Serbia received significantly more hours of mathematics teaching per week than other students in the region (Fig. 5). The time spent on science lessons showed even greater variation, ranging from an average time of $92 \mathrm{~min}$ per week in Albania to 137 min per week in Croatia.

According to the TIMSS 2019 data, the amount of instructional time that students spent in classrooms per week varied widely by subject in the Dinaric region (Fig. 5). In four of the education systems (Albania, Kosovo, Montenegro, and Serbia) grade four students spent at least twice as much time on mathematics compared to science. Across the region, students from Serbia (245 min per week) and Kosovo (240 min per week) spent the greatest amount of time on learning mathematics, while students from Croatia devoted the greatest amount of time to learning science (137 min per week). Recent research has shown that the amount of time that students spend on 


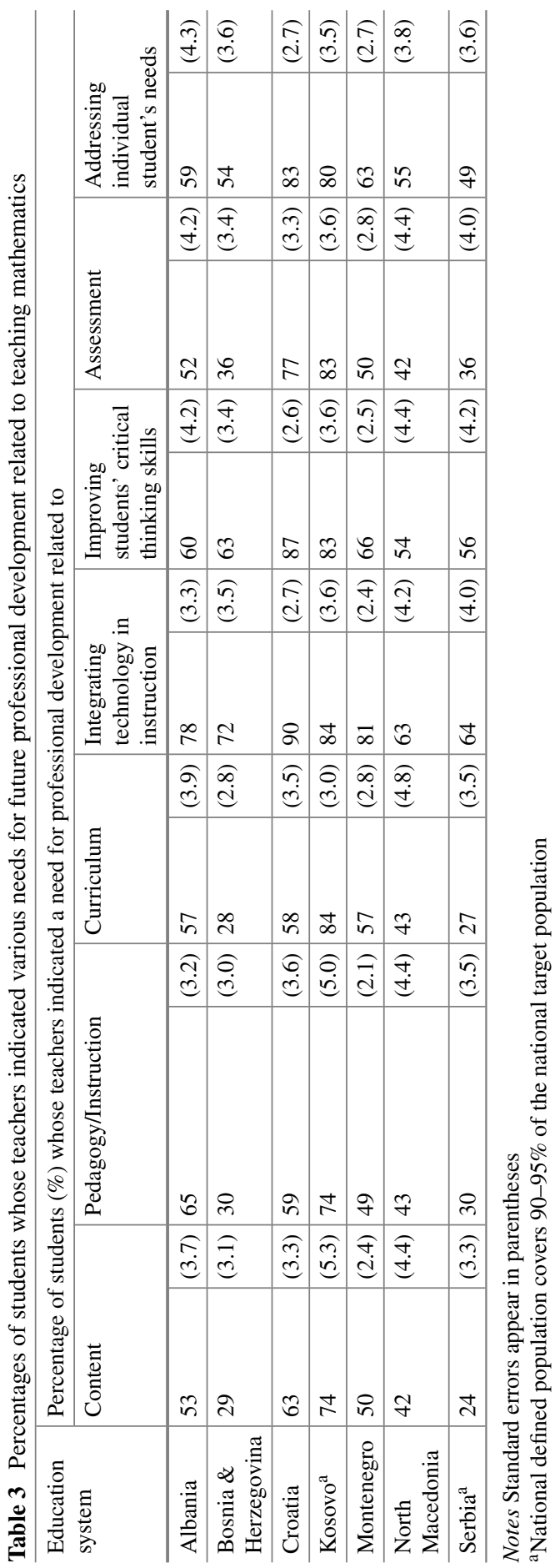




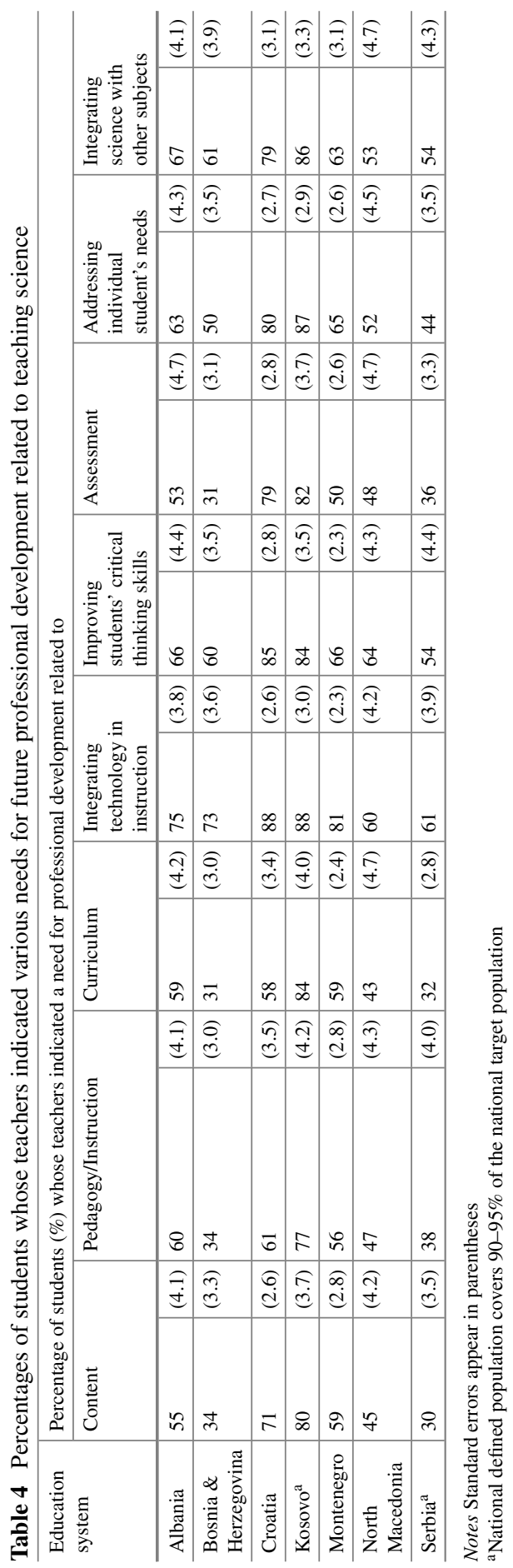




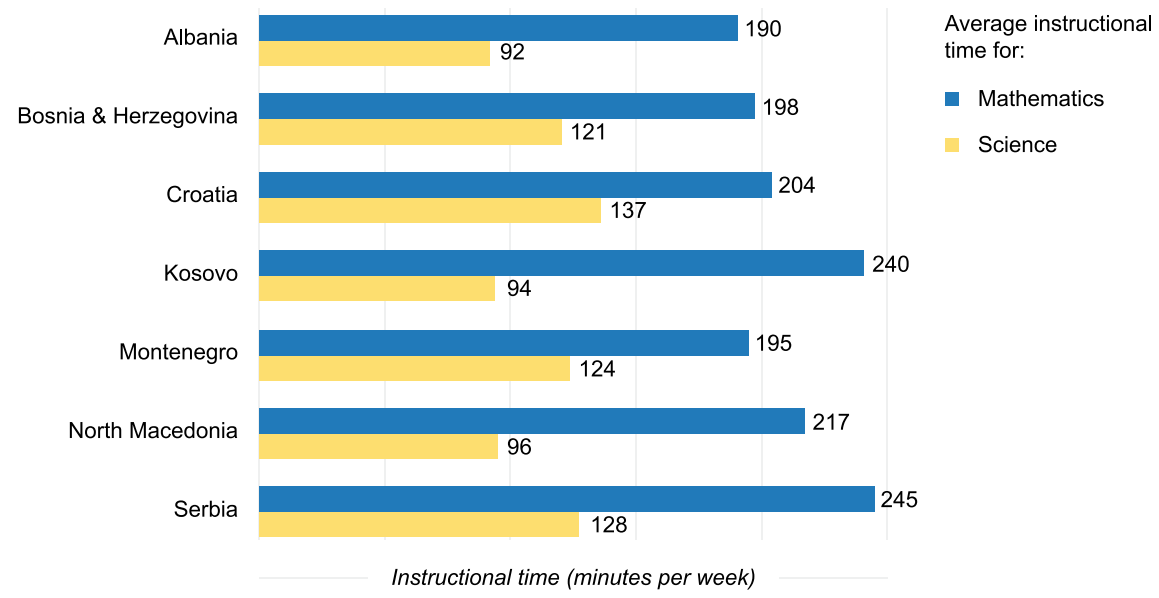

Fig. 5 Average instructional time spent on teaching mathematics and science per week (minutes) Note In Kosovo and Serbia, the national defined population covers $90-95 \%$ of the national target population

learning mathematics and science on weekly basis in Eastern European education systems is significantly related to student achievement (Lavy, 2015). Some authors have suggested that, based on extended analysis of international data, "differences in instruction time play a less important role than previously thought for explaining international gaps in student achievement" (Bietenbeck \& Collins, 2020, p. 9); however, this divergence among international studies may be partly due to the differing criteria used to measure instruction time in the international data.

Teachers in different education systems have different teaching styles, shaped by beliefs and attitudes about teaching, and what they have learned during their initial teacher preparation programs and during subsequent PD. To better understand those different teaching styles, and investigate which styles were more successful, the TIMSS 2019 teacher questionnaire asked about specific activities that teachers undertook during their mathematics and science lessons (Tables S.12 and S.13 provide more detailed results for both mathematics and science, respectively; see supplementary materials at www.iea.nl/publications/RfEVol13). A very high percentage of grade four students ( $>80 \%$ ) had teachers who stated that in almost half of the mathematics lessons, students listened while teachers explained new content in mathematics or demonstrated new ways of problem solving or just memorizing rules, procedures, and facts. More than $90 \%$ of students across the whole region were asked by their teachers in at least half of their mathematics lessons to practice procedures on their own and apply what they have learned to new problem situations, except in Albania and Kosovo, where this percentage was drastically lower. In all participating education systems, working in mixed ability groups was more common than working in groups with similar abilities for both mathematics and science lessons. In science classes, the most common instruction activities that grade four teachers from the 
region applied were explaining new content to the students, reading textbooks and other sources, and memorizing facts and principles. Observing and describing natural phenomena, such as weather or plant growth, was also frequently done. Teachers were less likely to ask students to work more independently and creatively, or to work on activities requiring higher order cognitive skills. Examples of such activities include designing and conducting experiments, presenting, and interpreting results and using them to draw conclusions. It is noticeable that, according to the teachers' reports, students in Albania and North Macedonia engaged in such activities more often than other students in the Dinaric region.

In teaching mathematics and science in the Dinaric region, the instructional methods of problem-solving, research, and experimental teaching methods were not sufficiently represented. Our results can be compared with a previous analysis of TIMSS 2015 data for teaching practices in Serbia, Croatia, and Hungary (Đerić et al., 2017). TIMSS 2019 results showed that most students of the teachers in the region implemented procedures that were more teacher-centered, while students played largely passive roles during mathematics and science classes. For example, the data indicate that students of science listened to teachers explain concepts, read lessons from the textbooks, and they remembered the facts and principles (Mullis et al., 2020). These instructional practices are very important when building the basic knowledge of younger students, especially in the fields of mathematics and science. Nevertheless, it was relatively rare for teachers to use innovative teaching practices, such as asking their students to plan and conduct experiments or work in the field and outside the classroom; this reinforces earlier TIMSS findings in Serbia (Mirkov \& Lalić Vučetić, 2018), as well as in other education systems in the region (Martin et al., 2016; Mullis et al., 2016, 2020).

PISA 2018 also found that teachers in this region were using less adaptive instruction and more teacher-directed instruction (OECD, 2020). Teachers may choose more traditional roles and procedures, believing that these are effective ways of working with grade four students, or they may lack the confidence (either in themselves or their students) to apply more innovative methods. But, with appropriate support, students of this age can be effectively engaged in investigation, gathering and analyzing data, and in drawing conclusions based on evidence (Đerić et al., 2017, 2020; Mullis et al., 2020).

Students participating in TIMSS 2019 reported that they know what their teachers expect from them, that the teachers explain contents clearly, and that teachers answer their questions and provide help and support in learning. Compared to their peers across the region, students from Croatia and Serbia were less likely to agree that their teachers applied these instructional practices in mathematics and science classes (Mullis et al., 2020). It seems that students in the Dinaric region generally perceive traditional forms of teaching and learning as engaging. Fauth et al. (2014) stressed that it was necessary to be cautious when interpreting such data because, with students of this age, the overall popularity of the teacher affects the student's evaluation of the quality of their classes. 


\subsection{Relationship Between Teacher Quality and Instructional Practice in the Dinaric Region}

Recent evidence from international studies has suggested that teacher quality is significantly related to instructional quality (Blömeke et al., 2016). To establish whether teacher quality was related to instructional practice across the Dinaric region, we investigated the quality of teachers as a construct expressed by the length of their teaching experience, level of formal education, and time dedicated to PD (more than 15 hours), and examined the relationship of this construct with instructional practice of teachers for both mathematics and science. However, we found that there was no consistent relationship between teacher quality and instructional quality across the Dinaric region; teacher quality indicators were related to only a few aspects of instructional practice or not at all. In some cases, teachers who were more experienced and better educated, and those who spent more time on PD activities, appeared to be more willing to use cognitive-activation strategies that require students to use higher levels of thinking (e.g., use evidence from experiments or investigations to support conclusions).

\subsection{Instructional Practice as a Factor in Student Achievement in the Dinaric Region}

To investigate whether the characteristics of teachers and classes can be used as predictors of student achievement in mathematics and science, we undertook multivariate linear regression analyses (see Chapter 1). Such multilinear modeling aims to answer whether the instructional practice of teachers is related to student achievement when teacher quality variables are controlled, and vice versa. Both mathematics and science models explained less than three percent of the variance in student achievement in mathematics and science; few predictors were significant, and their contributions were small (Tables 5 and 6). Thus, even if the factors related to professional characteristics of teachers and the quality of their teaching had shown to be significant predictors of achievement, they would only have explained a small amount of the achievement in mathematics and science.

Across the Dinaric region, we found that teacher quality measures were not statistically significantly predictors of student achievement in mathematics and science, although there were some exceptions where their level of formal education and years of the working experience had an effect (see Sect. 4.3). Our findings are consistent with other studies that noted "measurable" teacher characteristics explained only a small portion of the variance in student achievement (Đerić et al. 2017; Munoz and Chang 2007), and this creates a clear dilemma for policymakers. In general, this lack of variance in developed education systems contributes to the problems associated with observing an impact on learning outcomes. So, instead of focusing on identifying differences among teachers who have increasingly similar backgrounds, it is 


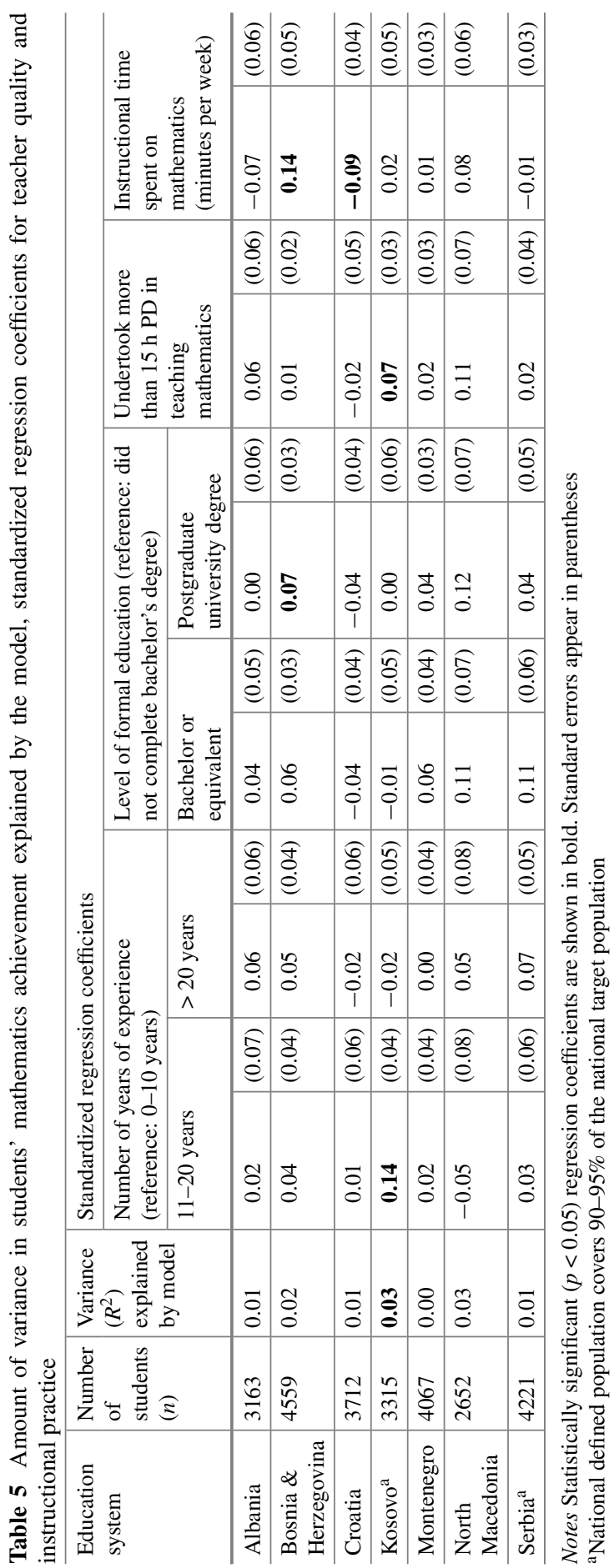




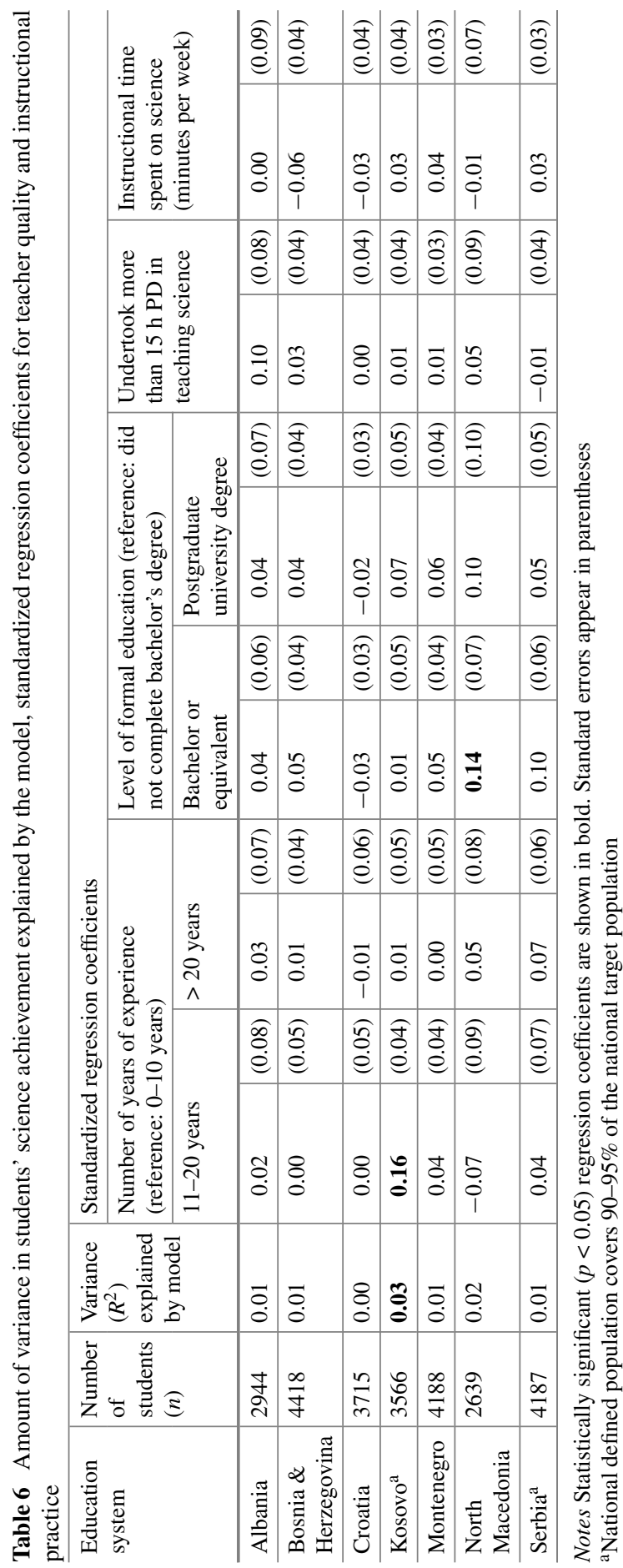


equally important to improve the processes involved in the preparation, recruitment, mentoring, promotion, and dismissal of teachers (Rivkin et al. 2005).

\section{Conclusions}

There were previously few national and/or regional studies examining the relationships between teacher quality, instructional practice, and student outcomes in the Dinaric region. Here, we were able to use data based on representative samples of grade four students from TIMSS 2019, together with TIMSS measures of teacher quality and instructional practice, to analyze the contribution of these teacher variables to student achievement in mathematics and science across the Dinaric region.

The educational background of mathematics and science teachers is similar across the Dinaric region. Teacher education in the region increasingly follows existing EU requirements. Most students in the Dinaric region have teachers who, on average, are slightly more experienced than their colleagues in other education systems that participated in TIMSS 2019, however, the level of PD for those teaching mathematics and sciences is quite low across the Dinaric region. Responses to the TIMSS 2019 teacher questionnaire indicate that mathematics and science teachers in the region are aware of which competencies they should develop in students and that they need support in acquiring more innovative teaching methods. The future needs for PD that they identified are consistent with current trends in the field of education and new social circumstances regarding the use of ICT. Decision makers should take these teacher observations into account and adjust future PD activities accordingly. Facilitating easier access to PD opportunities and raising the quality and relevance of these programs can also increase teacher participation and help teachers to strengthen their practice, knowledge, and skills (OECD, 2020). Policymakers and teachers in the Dinaric region could use this information to improve PD and control the successful implementation of changes in the next TIMSS cycle.

According to our analyses, teacher quality measures were not statistically significant predictors for student achievement in mathematics and science in most education systems in the Dinaric region. Teacher quality was related only to some aspects of instructional practice. TIMSS 2019 data (Mullis et al., 2020) showed that most teachers in the Dinaric region based their standard practice on more traditional teacher-centered activities (e.g., students read lessons from the textbooks and remember the facts and principles), while modern teaching methods suggest that it is beneficial for students to play more active roles in mathematics and science classes. Dinaric teachers who are more educated, more experienced, and those who spend more time on PD activities are more willing to use cognitive-activation strategies that require students to use higher cognitive levels of thinking (e.g., use evidence from experiments or investigations to support conclusions). 
Even though teacher quality and instructional practice have not been shown as key factors in predicting student achievement in mathematics and science, their importance should not be overlooked. It is necessary to be cautious when interpreting the results and to carefully review the different aspects. Precisely which characteristics and behaviors of teachers in the classroom affect student achievement in the Dinaric region remains unclear. Effectiveness studies conducted over several decades on diverse hierarchical levels (individual, class, and school level) provide some answers (Creemers \& Kyriakides, 2008), giving us an opportunity to get closer to describing the ideal profile of an efficient teacher, who can optimally guide and support their students. Such studies provide information on possible identification and systematization of student, teacher, and school characteristics that influence achievement, enabling improvement in teaching practices and overall quality (Teodorovic, 2011).

\section{References}

Barrera-Pedemonte, F. (2016). High-quality teacher professional development and classroom teaching practices: Evidence from TALIS 2013. OECD Education Working Papers, No. 141. OECD Publishing. https://doi.org/10.1787/5jlpszw26rvd-en

Bietenbeck, J., \& Collins, M. (2020). New evidence on the importance of instruction time for student achievement on international assessments. Working Papers, no. 2020: 18. Lund University, Department of Economics. https://ideas.repec.org/p/hhs/lunewp/2020_018.html

Blömeke, S., Olsen, R. V., \& Suhl, U. (2016). Relation of student achievement to the quality of their teachers and instructional quality. In T. Nilsen \& J.-E. Gustafsson (Eds.), Teacher quality, instructional quality, and student outcome: Relationships across countries, cohorts, and time (pp. 21-50). Springer Open. https://doi.org/10.1007/978-3-319-41252-8

Burroughs, N., \& Chudgar, A. (2017). The role of teacher quality in fourth-grade mathematics instruction: Evidence from TIMSS 2015 (Policy brief No. 16). International Association for the Evaluation of Educational Achievement. https://www.iea.nl/publications/series-journals/policybrief/october-2017-role-teacher-quality-fourth-grade

Creemers, B. P. M., \& Kyriakides, L. (2008). The dynamics of educational effectiveness: A contribution to policy, practice, and theory in con-temporary schools. Routledge.

Decristan, J., Kunter, M., Fauth, B., Büttner, G., Hardy, I., \& Hertel, S. (2016). What role does instructional quality play for elementary school children's science competence? A focus on students at risk. Journal for Educational Research Online, 8(1), 66-89. https://www.pedocs.de/volltexte/2016/12032/pdf/JERO_2016_1_Decristan_et_al_ What_role_does_instructional_quality.pdf

Duda, A., Golubeva, M., \& Clifford-Amos, T. (2013). Teacher education and training in the Western Balkans. Final synthesis report. Publications Office of the European Union. https://ec.europa.eu/ assets/eac/education/library/study/2013/teacher-balkans_en.pdf

Đerić, I., Milin, V., \& Stanković, D. (2014). Pravci unapređivanja stručnog usavršavanja u Srbiji: perspektive različitih aktera [Directions of improving the quality of in-service teacher training in Serbia: The perspectives of different participants]. Zbornik Instituta Za Pedagoška Istraživanja [Journal of the Institute for Educational Research], 46(1), 29-49.

Đerić, I., Stančić, M., \& Đević, R. (2017). Kvalitet nastave i postignuće učenika u matematici i prirodnim naukama [The quality of teaching and student achievement in mathematics and science]. In M. Marušić Jablanović, N. Gutvajn, \& I. Jakšić (Eds.), TIMSS 2015 u Srbiji. Rezultati međunarodnog istraživanja postignuća učenika 4. razreda osnovne škole iz matematike i prirodnih nauka [TIMSS 2015 in Serbia. Results of an international study on the achievements of 4th grade 
elementary school students in mathematics and sciences] (pp. 149-182). Institute for Educational Research.

Đerić, I., Gutvajn, N., Jošić, S., \& Ševa, N. (2020). Nacionalni izveštaj: TIMSS 2019 u SrbijiPregled osnovnih nalaza [National Report: TIMSS 2019 in Serbia-Overview of basic findings]. Institute for Educational Research.

Goe, L. (2007). The link between teacher quality and student outcomes: A research synthesis national comprehensive center for teacher quality. Education Commission of the States, ETS, Learning Point Associates, and Vanderbilt University. https://gtlcenter.org/sites/default/files/docs/LinkBe tweenTQandStudentOutcomes.pdf

Elezović, I., \& Muraja, J. (2020). Croatia. In D. L. Kelly, V. A. S. Centurino, M. O. Martin \& I. V. S. Mullis (Eds.), TIMSS 2019 Encyclopedia: Education policy and curriculum in mathematics and science. TIMSS \& PIRLS International Study Center, Boston College. https://timssandpirls. bc.edu/timss2019/encyclopedia/

Fauth, B., Decristan, J., Rieser, S., Klieme, E., \& Büttner, G. (2014). Student ratings of teaching quality in primary school: Dimensions and prediction of student outcomes. Learning and Instruction, 29, 1-9. https://doi.org/10.1016/j.learninstruc.2013.07.001

Fishbein, B., Foy, P., \& Yin, L. (2021). TIMSS 2019 user guide for the international database. TIMSS \& PIRLS International Study Center, Boston College. https://timssandpirls.bc.edu/tim ss2019/international-database/

IEA. (2021). ICILS. International Computer and Information Literacy Study. International Association for the Evaluation of Educational Achievement. https://www.iea.nl/studies/iea/icils

Johansson, S., \& Myberg, E. (2019). Teacher specialization and student perceived instructional quality: What are the relationships to student reading achievement? Educational Assessment Evaluation and Accountability, 31, 177-200. https://doi.org/10.1007/s11092-019-09297-5

Lavy, V. (2015). Do differences in schools' instruction time explain international achievement gaps? Evidence from developed and developing countries. The Economic Journal, 125, F397-F424. https://doi.org/10.1111/ecoj.12233

Liang, G., Zhang, Y., Huang, H., Shishan, Shi., \& Qiao, Z. (2015). Professional development and student achievement: International evidence from the TIMSS data. Postdoc Journal, 3(2), 1731. http://www.postdocjournal.com/archives/767/professional-development-and-student-achiev ement-international-evidence-from-the-timss-data.htm

Martin, M. O., Mullis, I. V. S., Foy, P., \& Hooper, M. (2016). TIMSS 2015 international results in science. TIMSS \& PIRLS International Study Center, Boston College. http://timssandpirls.bc. edu/timss2015/international-results/

Martin, M. O., von Davier, M., \& Mullis, I. V. S. (Eds.). (2020). Methods and procedures: TIMSS 2019 technical report. TIMSS \& PIRLS International Study Center, Boston College. https://tim ssandpirls.bc.edu/timss2019/methods

Mehmeti, S., Rraci, E., \& Bajrami, K. (2019). Teacher professional development in Kosovo. Kosovo Education and Employment Network: KEEN project. https://www.keen-ks.net/site/assets/files/ 1467/zhvillimi_profesional_i_mesimdhenesve_ne_kosove_eng.pdf

Mirkov, S., \& Lalić Vučetić, N. (2018). Izazovi u realizaciji nastave: TIMSS 2015 kao izvor saznanja o odnosu učitelja prema radu [Teaching challenges: TIMSS 2015 as a source of information about primary school teachers' attitudes towards their work]. Inovacije u Nastavi [Teaching Innovations], 31(3), 1-19.

Mićanović, V., \& Vučković, D. (2014). Some aspects of the primary education reform process in Montenegro from the perspective of teachers. Journal of Educational and Social Research, 4(4), 80-87. https://doi.org/10.5901/jesr.2014.v4n4p80

Mullis, I. V. S., Martin, M. O., Foy, P., \& Hooper, M. (2016). TIMSS 2015 international results in mathematics. TIMSS \& PIRLS International Study Center, Boston College. http://timssandpirls. bc.edu/timss2015/international-results/

Mullis, I. V. S., Martin, M. O., Foy, P., Kelly, D., \& Fishbein, B. (2020). TIMSS 2019 international results in mathematics and science. TIMSS \& PIRLS International Study Center, Boston College. http://timssandpirls.bc.edu/timss2019/international-results/ 
Nilsen, T., \& Gustafsson, J.-N. (2016). Teacher quality, instructional quality and student outcomes: Relationships across countries, cohorts and time. Springer.

Nilsen, T., Scherer, R., \& Blömeke S. (2018). The relation of science teachers' quality and instruction to student motivation and achievement in the 4th and 8th grade: A Nordic perspective. In T. Nilsen, R. Scherer, \& S. Blömeke (Eds.), Northern lights on TIMSS and PISA 2018 (pp. 61-94). The Nordic Council of Ministers. https://www.udir.no/contentassets/24c699db4e104200ad605 41bf54846c6/northern_lights_on_timss_and_pisa_2018.pdf

OECD. (2009). Creating effective teaching and learning environments: First results from TALIS. OECD Publishing. https://www.oecd.org/education/school/43023606.pdf

OECD. (2019a). OECD review of evaluation and assessment in education in North Macedonia: assessment and recommendation. OECD Reviews of Evaluation and Assessment in Education. OECD Publishing. https://doi.org/10.1787/079fe34c-en

OECD. (2019b). TALIS 2018 results (Volume I): Teachers and school leaders as lifelong learners. OECD Publishing. https://doi.org/10.1787/1d0bc92a-en

OECD. (2020). Education in the Western Balkans: Findings from PISA. OECD Publishing. https:// doi.org/10.1787/764847ff-en

Pantić, N., Wubbels, T., \& Mainhard, T. (2011). Teacher competence as a basis for teacher education: Comparing views of teachers and teacher educators in five Western Balkan countries. Comparative Education Review, 55(2), 165-188. https://doi.org/10.1086/657154

Popić, B., \& Džumhur, Ž. (2020). Bosnia. In D. L. Kelly, V. A. S. Centurino, M. O. Martin, \& I. V. S. Mullis (Eds.), TIMSS 2019 Encyclopedia: Education policy and curriculum in mathematics and science. TIMSS \& PIRLS International Study Center, Boston College. https://timssandpirls. bc.edu/timss2019/encyclopedia/

Protner, E. (Ed.) (2020). Razvoj i aktualne tendencije pedagogije i školstva na području nekadašnje Jugoslavije/Development and Current Trends of Pedagogy and Education in the Former Yugoslavia. University of Maribor.

Schleicher, A. (2020). Teaching and Learning International Survey TALIS 2018. Insights and Interpretations. OECD Publishing. http://www.oecd.org/education/talis/TALIS2018_insights_and_ interpretations.pdf

Teodorovic, J. (2011). Classroom and school factors related to student achievement: What works for students? School Effectiveness and School Improvement, 22(2), 215-236. https://doi.org/10. 1080/09243453.2011.575650

TIMSS \& PIRLS International Study Center. (2018). Teacher questionnaire. Grade 4. TIMSS \& PIRLS International Study Center, Boston College. https://timssandpirls.bc.edu/timss2019/que stionnaires/pdf/T19_TQ_4.pdf

UNESCO Institute of Statistics. (2012). International standard classification of education (ISCED) 2011. UNESCO Institute of Statistics. http://uis.unesco.org/sites/default/files/documents/intern ational-standard-classification-of-education-isced-2011-en.pdf

United Nations. (1999). Resolution 1244 (1999). Adopted by the Security Council at its 4011th meeting, on 10 June 1999. United Nations Security Council. https://digitallibrary.un.org/record/ $274488 ? \ln =$ en

Viorel, S. (2017). The teaching profession in Europe: Practices, perceptions, and policies. Eurydice Report. Publications Office of the EU. https://op.europa.eu/s/oMEu

Vrapi, R., \& Alia, A. (2020). Albania. In D. L. Kelly, V. A. S. Centurino, M. O. Martin, \& I. V. S. Mullis (Eds.), TIMSS 2019 encyclopedia: Education policy and curriculum in mathematics and science. TIMSS \& PIRLS International Study Center, Boston College. https://timssandpirls.bc. edu/timss2019/encyclopedia/

Ivana Đerić holds a Ph.D. in pedagogy. She was a researcher at the Institute for Educational Research, Belgrade, and professor of pedagogy at the Faculty of Science in Kragujevac, Serbia. She was national research coordinator for TIMSS 2019 and LaNA 2019 in Serbia and is author of scientific papers in national and international journals and publications. She participated in the 
development of the professional development model for EC educators and teachers, "Professional learning communities of practitioners," and for in-service trainings which have obtained national accreditation. Her professional interests include student achievement, motivation, and autonomy, project-based learning, and teacher professional development.

Ines Elezović has been employed with the National Centre for External Evaluation of Education since 2008, working in the Research and Development Department and then in the Department for Quality Assurance in Education. At present, she is working on international projects as national research coordinator for the IEA PIRLS, TIMSS, and ICCS surveys. Drawing on acquired knowledge and work experience she has specialized in the sociology of education, methodology of large scale assessments, and research project cycles in education.

Falk Brese is a senior research analyst at IEA's Research and Analysis Unit. His research interests are in social inequalities and immigration, the transition of research results from reporting to policy implementation, as well as international large-scale assessment (ILSA) methodology. He has worked at IEA since 2000 and has ample experience with the implementation of ILSAs and analyzing respective data. He has a background in political science with a focus on policy formation and implementation.

Open Access This chapter is licensed under the terms of the Creative Commons AttributionNonCommercial 4.0 International License (http://creativecommons.org/licenses/by-nc/4.0/), which permits any noncommercial use, sharing, adaptation, distribution and reproduction in any medium or format, as long as you give appropriate credit to the original author(s) and the source, provide a link to the Creative Commons license and indicate if changes were made.

The images or other third party material in this chapter are included in the chapter's Creative Commons license, unless indicated otherwise in a credit line to the material. If material is not included in the chapter's Creative Commons license and your intended use is not permitted by statutory regulation or exceeds the permitted use, you will need to obtain permission directly from the copyright holder.

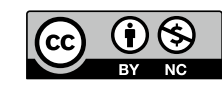

